\title{
PREVALENCE AND IMPLICATIONS OF COXSACKIE VIRUS IN MYOPERICARDITIS, PROSPECTIVE TERTIARY CARE STUDY
}

Mohd. Ismail1 ${ }^{1}$, Najeeb Rasool ${ }^{2}$, Aamir Rashid ${ }^{3}$, Masood Tanviri, Mohammad Ashraf5, Aaqib Zaffar 6 , Sayed Arshad ${ }^{7}$

${ }^{1}$ Associate Professor, Department of Medicine, GMC, Srinagar.

${ }^{2}$ Senior Resident, Department of Medicine, GMC, Srinagar.

3 Post Doctoral Fellow, Paediatric Cardiology, SCTIMST, Trivandrum.

4 Professor, Department of Medicine, GMC, Srinagar.

${ }^{5}$ Lecturer, Department of Medicine, GMC, Srinagar.

${ }^{6}$ Postgraduate Scholar, Department of Paediatrics, SKMIS, Srinagar.

${ }^{7}$ Associate Professor, Department of Radiotherapy, GMC, Srinagar.

\section{ABSTRACT}

The serological prevalence of coxsackie virus in myocarditis, pericarditis and myopericarditis is largely unknown in our population. The implications of coxsackie virus as causative agent in myopericarditis has not been studied so far in our population.

\section{AIMS AND OBJECTIVES}

The aims and objectives of this study were to study the serological prevalence of Coxsackie virus in acute pericarditis and myocarditis in a Tertiary Centre and to study the clinical profile of Coxsackie myopericarditis.

\section{MATERIAL AND METHODS}

Our study was a prospective study done from November 2010 - October 2012, the samples were taken from 40 patients with the diagnosed cases of myocarditis, pericarditis and myopericarditis. Myocarditis and pericarditis were diagnosed as per standard guidelines, Enzyme Immunoassay (ELISA) for the determination of IgM antibodies to Coxsackie virus B (CoxB) in human acute and convalescent sera was done.

\section{RESULTS}

Our study comprised of forty patients with mean age of 35.3 years with M:F ratio of 1.35 . Among the 40 patients 11 patients were diagnosed with pericarditis (27.50\%), 14 with myocarditis (35.00\%) and 15 patients with myopericarditis (37.50\%). Among the 40 studied patients, 15 were positive for Coxsackie serology. Among the serology positive patients, 6 had diagnosis of myopericarditis (40.00\%), 6 had diagnosis of myocarditis (40.00\%) and 3 had diagnosis of pericarditis (20.00\%). The clinical features of coxsackie positive and negative individuals did not differ significantly; breathlessness (93\% vs 76\%), chest pain (73\% vs $76 \%$ ), fever ( $60 \%$ vs $60 \%$ ), cough ( 46 vs $32 \%$ ), CCF ( 53 vs $48 \%$ ) respectively. Ejection fraction less than $45 \%$ was seen in $40 \%$ of positive vs $32 \%$ of serology negative patients.

\section{CONCLUSION}

Coxsackie virus as an aetiological factor was found in about one-third of cases of acute myopericarditis. However, the clinical presentation and echocardiographic characteristics did not differ from Coxsackie negative myopericarditis.

\section{KEYWORDS}

Myocarditis, Pericarditis, Coxsackie Virus.

HOW TO CITE THIS ARTICLE: Ismail M, Rasool N, Rashid A, et al. Prevalence and implications of coxsackie virus in myopericarditis, prospective tertiary care study. J. Evolution Med. Dent. Sci. 2016;5(62):4382-4386, D0I: $10.14260 /$ jemds/2016/1000

\section{INTRODUCTION}

Pericarditis is an acute inflammatory disease of pericardium. It is characterised by typical chest pain, pericardial rub, widespread saddle shaped or concave shaped upward ST elevation on electrographic pericardial effusion, fever, high erythrocyte sedimentation rate and high C-reactive protein. ${ }^{(1,2)}$ The chest pain typically is retrosternal in location, sudden in onset and exacerbated by inspiration. It is often worse when the patient is supine and improves when he or she sits upright and leans forward. Myocarditis refers to

Financial or Other, Competing Interest: None.

Submission 26-06-2016, Peer Review 19-07-2016,

Acceptance 26-07-2016, Published 04-08-2016.

Corresponding Author:

Aamir Rashid,

House No. 8, Old Colony,

Goripora, Srinagar-190005,

Jammu and Kashmir, India.

E-mail: aamirrashid11@yahoo.co.in

DOI: $10.14260 /$ jemds $/ 2016 / 1000$ inflammation of heart muscle. Inflammation can be found after any form of injury to the heart including ischaemic damage, mechanical trauma and genetic cardiomyopathies. However, classic myocarditis refers to the inflammation of the heart muscle as a result of exposure to either discrete external antigens such as viruses, bacteria, parasites and drugs or internal triggers such as autoimmune activation against self-antigen.(3)

Idiopathic pericarditis comprises $80-90 \%$ of the cases occurring in immunocompetent patients from developed countries. An infectious or systemic aetiology cannot usually be identified in these cases using standard laboratory techniques in the real world. Tuberculosis is found in approximately $5 \%$ of cases, neoplasms in $5 \%$ of cases. The commonest viral infections causing pericarditis include Coxsackie virus A and B, Echo virus, adenovirus, parvovirus B19, Human Herpes virus 6.

The Coxsackie viruses were discovered in 1948-49 by Dr. Gilbert Dalldorf, a scientist working at the New York State 
Department of Health in Albany, New York. The virus family he discovered was eventually given the name Coxsackie for the town of Coxsackie, New York, a small town on the Hudson River where Dalldorf had obtained the first faecal specimens. ${ }^{[4]}$ Coxsackie viruses are members of the Picornaviridae family and fall into groups A and B, defined by their pathogenicity in newborn mice.[5] The Coxsackie group $B$ viruses are now increasingly recognised as a cause of myocarditis with or without pericarditis. Coxsackie myocarditis in neonates was first described from Southern Rhodesia (Montgomery et al 1955).[6] Similar small nursery epidemics were later reported elsewhere including Amsterdam (Van Creveld and De Jager, 1956).[7] Fletcher and Brennan ${ }^{[8]}$ in Northern Ireland first reported the case of a man with pericarditis due to Coxsackie B4 virus and numerous adult cases have since been reported (Gordon, Lennette and Sandrock 1959)[9]; Null and Castle, 1959[10]; Sainani, Krompotic and Slodki, 1968[11]; Bell and Grist, 1968.[12] Coxsackie virus causing human myocarditis and pericarditis is limited to isolation of virus from myocardium as reported from Sutton et al 1967,[13] Longson et al 1969.[14] A moderate order association of Coxsackie $B$ with myocarditis has been made by correlation of neutralizing antibodies titres or by isolation of virus from rectal and nasopharyngeal swab with acute myocarditis (Bell and Grist 1968,[15] Freij et al 1970,[16] Smith 1970,[17] Koontz and Ray 1971,[18] Toshima et al 1979.[19])

The clinical profile and treatment outcomes of Coxsackie myopericarditis is largely unknown in our population. This study was undertaken to study the role of Coxsackie virus in myopericarditis in our population.

\section{AIMS AND OBJECTIVES}

\section{The Aims and Objectives of this study were}

1. To study the serological prevalence of Coxsackie virus in acute pericarditis and myocarditis in a Tertiary Centre.

2. To study the clinical profile of Coxsackie myopericarditis.

\section{METHODS}

Our study was a prospective study done from November 2010-October 2012, the samples were taken from 40 patients with the diagnosed cases of myocarditis, pericarditis and myopericarditis.

\section{A Clinical Diagnosis of Acute Pericarditis was made when at least 2 of the Criteria were Present}

- Pericarditic typical chest pain.

- Pericardial friction rubs.

- Widespread ST segment elevation or PR depressions not previously reported.

- New or worsening pericardial effusion.

A Clinical Diagnosis of Myopericarditis was performed in Patients with Diagnostic Criteria for Acute Pericarditis and 1 of the following Features

- Evidence of elevated cardiac enzymes (creatine kinaseMB fraction or troponin I or T); or

- New onset of focal or diffuse depressed left ventricular function by echocardiography. The study of each patient included a good clinical history, physical examination, haemogram, KFT, LFT, ECG, Echocardiography. For viral studies, the first blood sample was collected within 48 hours of admission and second sample was taken 6 weeks after first sample.

- Sera was extracted from the blood samples immediately and then stored at - 70C.

Enzyme Immunoassay (ELISA) for the determination of IgM antibodies to Coxsackie virus $B$ (CoxB) in human acute and convalescent sera was done.

\section{Principle of the Test}

- Microplates for ELISA are pre-coated with native Coxsackie virus B antigens derived from tissue culture containing its major subtypes (Commercial kits).

- In the 1 st incubation, the solid phase is treated with diluted samples and anti-CoxB IgM are captured, if present, by the antigens.

- After washing out all the other components of the sample, in the 2nd incubation bound anti-CoxB IgM are detected by the addition of anti-hIgM antibody, labelled with peroxidase (HRP).

- The enzyme captured on the solid phase, acting on the substrate/chromogen mixture, generates an optical signal that is proportional to the amount of anti-CoxB IgM antibodies present in the sample.

- The presence of IgM in the sample may therefore be determined by means of a cut-off value, able to discriminate between negative and positive samples.

- Neutralization of IgG anti-CoxB, carried out directly in the well, is performed in the assay in order to block interferences due to this class of antibodies in the determination of IgM.

\section{RESULTS}

Our study comprised of forty patients with range of age from 13-70 years. Mean age was 35.3 years. There were 23 males and 17 females with M:F ratio of 1.35 and the mean age among males was 35.65 and among females was 35.35 years. The main symptoms and signs are shown in Table 1 . Among the 40 patients, 11 patients were diagnosed with pericarditis (27.50\%), 14 with myocarditis (35.00\%) and 15 patients with myopericarditis (37.50\%). The distribution of patients as per Seropositivity for Coxsackie is shown in Table 2. The rate of positivity among myocarditis group was $42.9 \%$, among pericarditis was $27.3 \%$ and among myopericarditis was $40 \%$. Among the 40 studied patients, 15 were positive for Coxsackie serology evidenced by either four-fold rise of serum antibody titres or very high titres during the acute phase. Among the serology positive patients 6 had diagnosis of myopericarditis $(40.00 \%), 6$ had diagnosis of myocarditis $(40.00 \%)$ and 3 had diagnosis of pericarditis $(20.00 \%)$. Among the 15 patients, 12 patients had four-fold rise of antibody titre and 3 patients had very high titres during the acute phase as shown in Table 3. Among the Coxsackie serology positive patients, 8 were males $(53.30 \%)$ and 7 were females $(46.70 \%)$. Among the Coxsackie serology negative patients, 15 were males $(60.00 \%)$ and 10 were females $(40.00 \%)$. The clinical features of Coxsackie positive individuals is shown in Table 4 . The clinical features were not different from the Coxsackie serology negative patients that presented with breathlessness $(76.00 \%)$; chest pain $(76.00 \%)$, fever $(60.00 \%)$, viral prodrome $(32.00 \%)$ cough $(32.00 \%)$; and vomiting (28.00\%). Among the Coxsackie 
serology positive patients $8 / 15$ (53.30\%) presented with features of CCF; among the 8 patients 4 (50.00\%) had diagnosis of myocarditis and $4(50.00 \%)$ had diagnosis of myopericarditis. No patient with diagnosis of pericarditis had features of CCF or out of 12 patients with myocardial involvement 8/12 (66.60\%) presented with features of CCF. Among the Coxsackie negative patients 12/25 (48.00\%) presented with features of CCF; among the 12 patients having features of CCF 7 had diagnosis of myopericarditis (58.33\%), 5 had diagnosis of myocarditis (41.6\%) and none among the pericarditis group had features of CCF. Out of 17 patients with myocardial involvement, 12 had features of CCF (70.5\%).

Among the Coxsackie serology positive patients $9 / 15 \mathrm{had}$ ejection fraction $>45(60.00 \%), 4 / 15$ had ejection fraction 35 45 (26.60\%), 2/15 had ejection fraction <35 (13.30\%). Among the 12 patients with myocardial involvement 6/12 $(50.00 \%)$ had ejection fraction $<45$. Among the Coxsackie serology negative patients $17 / 25$ had ejection fraction $>45$ (68.00\%), 5/25 had ejection fraction 35-45 (20.00\%), 3/25 had ejection fraction $<35(12.00 \%)$. Among the 17 patients with myocardial involvement 8/17, (47\%) had EF <45\%. Among the Coxsackie negative patients, 18/25 (72.00\%) had liver enzymes $<3$ URL and $7(28.00 \%)$ had liver enzymes $>3$ URL. Among the patients with $>3$ URL, all the 7 patients had myocardial involvement and no patient with only pericardial involvement had liver enzymes $>3$ URL. Among Coxsackie positive patients $10 / 15(66.60 \%)$ had liver enzymes $<3$ URL and $5 / 15$ (33.30\%) had liver enzymes $>3$ URL. Among the patients with $>3$ URL, all the 5 patients had myocardial involvement and no patient with only pericardial involvement had liver enzymes $>3$ URL. Among the Coxsackie serology negative patients, 5/25 $(20.00 \%)$ had ESR $<20$ $\mathrm{mm} / \mathrm{hr}$. and 20/25 (80.00\%) had ESR $>20 \mathrm{~mm} / \mathrm{hr}$. Among the Coxsackie serology positive patients, $1 / 15(6.70 \%)$ had ESR $<20 \mathrm{~mm} / \mathrm{hr}$. and 14/15 (93.30\%) had ESR >20 mm/hr. Among the Coxsackie serology negative patients, 17/25 $(68.00 \%)$ had WBC count $<11000$ and $8 / 25$ (32.00\%) had WBC count $>11000$. Among the Coxsackie serology positive patients, $8 / 15(53.30 \%)$ had WBC count $<11000$ and $7 / 15$ $(46.70 \%)$ had WBC count $>11000$.

\begin{tabular}{|c|c|}
\hline Symptom \& Signs & Number (Percentage) \\
\hline Fever & $24(60 \%)$ \\
\hline Breathlessness & $33(82 \%)$ \\
\hline Chest Pain & $30(75 \%)$ \\
\hline Cough & $15(37.5 \%)$ \\
\hline Vomiting & $8(20 \%)$ \\
\hline Viral Prodrome & $17(42.5 \%)$ \\
\hline Tachycardia & $27(67.5 \%)$ \\
\hline Rub & $19(47.5 \%)$ \\
\hline \multicolumn{2}{|c|}{ Table 1: Clinical Characteristics of Patients } \\
\hline
\end{tabular}

\begin{tabular}{|c|c|c|c|c|c|c|}
\hline & & & \multicolumn{4}{|c|}{ Diagnosis } \\
\hline & & & Myocarditis & Pericarditis & Myopericarditis & Total \\
\hline \multirow{4}{*}{$\begin{array}{l}\text { Coxsackie IgM } \\
\text { Antibody Rising } \\
\text { Titres }\end{array}$} & \multirow{2}{*}{ Negative } & $\mathrm{N}$ & 8 & 8 & 9 & 25 \\
\hline & & $\%$ & 57.10 & 72.7 & 60 & 62.5 \\
\hline & \multirow{2}{*}{ Positive } & $\mathrm{N}$ & 6 & 3 & 6 & 15 \\
\hline & & $\%$ & 42.90 & 27.30 & 40 & 37.5 \\
\hline \multirow{2}{*}{\multicolumn{2}{|c|}{ Total }} & $\mathrm{N}$ & 14 & 11 & 15 & 40 \\
\hline & & $\%$ & 100 & 100 & 100 & 100 \\
\hline \multicolumn{7}{|c|}{ Table 2: Distribution of Patients as per Serology } \\
\hline
\end{tabular}

\begin{tabular}{|c|c|c|c|c|c|}
\hline \multirow{2}{*}{ Case No. } & \multirow{2}{*}{ Age } & \multirow{2}{*}{ Sex } & \multirow{2}{*}{ Diagnosis } & \multicolumn{2}{|c|}{ Antibody Titre } \\
\cline { 5 - 6 } & & & Convalescent \\
\hline 1 & 32 & $\mathrm{~F}$ & Myopericarditis & $1 / 64$ & $1 / 512$ \\
\hline 2 & 40 & $\mathrm{~F}$ & Myopericarditis & $1 / 64$ & $1 / 512$ \\
\hline 3 & 45 & $\mathrm{~F}$ & Pericarditis & $1 / 64$ & $1 / 512$ \\
\hline 4 & 35 & $\mathrm{~F}$ & Pericarditis & $1 / 64$ & $1 / 512$ \\
\hline 5 & 27 & $\mathrm{~F}$ & Myocarditis & $1 / 128$ & $1 / 1024$ \\
\hline 6 & 26 & $\mathrm{~F}$ & Myocarditis & $1 / 1024$ & $1 / 1024$ \\
\hline 7 & 38 & $\mathrm{~F}$ & Myocarditis & $1 / 64$ & $1 / 1024$ \\
\hline 8 & 17 & $\mathrm{M}$ & Myocarditis & $1 / 64$ & $1 / 1024$ \\
\hline 9 & 19 & $\mathrm{M}$ & Myopericarditis & $1 / 1024$ & $1 / 1024$ \\
\hline 10 & 35 & $\mathrm{M}$ & Myopericarditis & $1 / 1024$ & $1 / 1024$ \\
\hline 11 & 32 & $\mathrm{M}$ & Myocarditis & $1 / 64$ & $1 / 1024$ \\
\hline 12 & 28 & $\mathrm{M}$ & Pericarditis & $1 / 128$ & $1 / 1024$ \\
\hline 13 & 26 & $\mathrm{M}$ & Myopericarditis & $1 / 64$ & $1 / 1024$ \\
\hline 14 & 70 & $\mathrm{M}$ & Myopericarditis & $1 / 64$ & $1 / 1024$ \\
\hline 15 & 46 & $\mathrm{M}$ & \multicolumn{2}{|c|}{ Myocarditis } & \\
\hline
\end{tabular}




\begin{tabular}{|c|c|c|c|c|}
\hline $\begin{array}{c}\text { Clinical } \\
\text { Parameter }\end{array}$ & $\begin{array}{c}\text { Myocarditis Number } \\
\text { (\%) }\end{array}$ & $\begin{array}{c}\text { Pericarditis } \\
\text { Number (\%) }\end{array}$ & $\begin{array}{c}\text { Myopericarditis } \\
\text { Number (\%) }\end{array}$ & $\begin{array}{c}\text { Total } \\
\text { Number (\%) }\end{array}$ \\
\hline Fever & $3(50)$ & $2(66.7)$ & $4(66.7)$ & $9(60)$ \\
\hline Breathlessness & $6(100)$ & $3(100)$ & $5(100)$ & $14(93.3)$ \\
\hline Chest Pain & $3(50)$ & $2(66.7)$ & $6(100)$ & $11(73.3)$ \\
\hline Cough & $2(33.3)$ & $2(66.7)$ & $3(50)$ & $7(46.7)$ \\
\hline Viral Prodrome & $5(83.3)$ & 0 & $4(66.7)$ & $9(60)$ \\
\hline Vomiting & 0 & 0 & $1(16.7)$ & $1(6.7)$ \\
\hline \multicolumn{2}{r}{} \\
\hline
\end{tabular}

\section{DISCUSSION}

We conducted a study to see the serological prevalence of Coxsackie $B$ virus in myocarditis, pericarditis and myopericarditis in a Tertiary Care Centre. Our study was conducted over a period of two years and included a total of 40 patients. Similar number of patients were admitted in studies conducted by Sainani et al[20] and A. G. Ferriera et al.[21] The number of patients in their studies were 55 over a period of 2 years and 15 over a period of 1 year respectively. The age of presentation in our study varied between 13 years and 70 years, which was comparable with the study conducted by M. Helin et al,[22] in which the age varied between 9 years and 65 years. Male-to-female sex ratio in our study was 1.35 , comparable with study conducted in Thailand by Naorawarut, Dechkum, Yoawapa Pangsawan et al in 19871989 (M:F=1.24).[23]

Out of total 40 patients studied 15 patients were positive for Coxsackie virus B serology (37.5\%), as proved by detection of IgM antibody to Group B Coxsackie virus.

Previous studies had proven variable results for positivity. In study conducted by Schmidt et al,[24] IgM antibodies to Coxsackie virus in myocarditis, pericarditis and pleurodynia group was $27 \%$ as compared to $8 \%$ in control group; $33.3 \%$ (5/15) positivity rate for Coxsackie virus was shown by A. G. Ferriera et al[21] in 1995 in Belem, Brazil. N. R. Grist and Eleanor J. Bell,[12] found that $1 / 3^{\text {rd }}$ cases of pericarditis and $1 / 2$ cases of myocarditis were associated with Coxsackie B virus infection. However, our study closely resembled Sainani et al[20] where 19 out of 55 patients (34.5\%) were positive for Coxsackie serology.

Among the pericarditis group Coxsackie virus serology was positive in $27.3 \%$, which closely resembled the study conducted by Schmidt et al (27\%) ${ }^{[24]}$ for pericarditis.

Coxsackie viral serology was positive in $42.5 \%$ of myocarditis group and similar results were shown by Novikov et al (40.9\%)[25] and El-Hagrassy MM et al (36.\%).[26] In patients diagnosed with myopericarditis, Coxsackie serology was positive in $40 \%$ comparable to Frisk G, Torfason EG and Diderholm H. (49\%).[27]

Among the 15 patients positive for Coxsackie serology, 12 patients showed $\geq 4$ fold rise in antibody titres in acute and convalescent sera, whereas 3 patients had very high titres only during the acute phase [Table 3] reflecting that the patients may have presented when the antibody titres had already peaked. Similar trends were shown in many patients by Helin et al[22] and David O'Neil, John D. McArthur et al,[28] where patients presented with significant high titres during the acute phase.

Among the Coxsackie serology positive patients, the clinical presentation in order of frequency was 14/15 had breathlessness (93.3\%); 11/15 had chest pain (73.3\%), 9/15 had fever (60\%), 9/15 had viral prodrome (60\%); 7/15 had cough (46.7\%); and 1/15 had vomiting (6.7\%) [Table 4]. The symptoms in our study were comparable to study conducted by Sainani et al[20] However, symptoms in Coxsackie serology negative patients were almost similar to Coxsackie serology positive patients.

Among the Coxsackie positive patients with myocardial involvement (Myocarditis and myopericarditis), 8/12 patients $(66.60 \%)$ presented with features of CCF which was comparable with other studies $(48,57)$. However, the proportion of patients who presented in CCF in Coxsackie serology negative patients were almost similar to that of serology positive patients ( $\mathrm{p}$ value: 0.744 ).

On echocardiography, ejection fraction $<45 \%$ was present in $6 / 12(50 \%)$ patients with myocardial involvement (myocarditis and myopericarditis) and reduced ejection fraction was present in $47.05 \%$ patients of Coxsackie serology negative patients [Table 13a; Fig 12a \& b], which was comparable with other studies.[29]

Neutrophilic leucocytosis and raised ESR was present in $46.70 \%$ (7/15) and 93.30\% (14/15) [Respectively, in Coxsackie serology positive patients and in Coxsackie serology negative patients neutrophilic leucocytosis and raised ESR was present in 32\% (8/25) and 80\% (20/25) with p-value of 0.354 and 0.381 respectively.

Our results were comparable with study conducted by M. Helin et al,[22] where ESR was elevated in all cases $(100 \%)$ and neutrophilic leucocytosis was present in 38.80\% (7/18).

Liver enzymes were elevated in about $33.30 \%(5 / 15)$ of Coxsackie serology positive patients and in Coxsackie serology negative patients it was raised in $28 \%(7 / 25)$ with $p$ value of 0.736 . The elevation of liver enzymes has been quite variable in previous studies by Koontz and Ray (15\%),[18] Sainani et al (63\%) ${ }^{[20]}$ and Hashimoto et al (100\%).[30] The variation in elevation of liver enzymes depends upon the time at which the samples were taken and also upon the severity of the illness of the patients as explained by Hashimoto et al.[30] Also in our study, only the patients with myocardial involvement (myocarditis and myopericarditis) showed elevation of liver enzymes and similar things were noticed by Hashimoto et al.[30]

\section{CONCLUSION}

Coxsackie virus as an aetiological factor was found in about one-third of cases of acute myopericarditis. However, the clinical presentation, echocardiographic and lab parameters did not differ from Coxsackie negative myopericarditis.

\section{REFERENCES}

1. Lange RA, Hillis LD. Acute pericarditis. N Engl J Med 2004;351:2195-202. 
2. Maisch B, Seferovic PM, Ristic AD, et al. Guidelines on the diagnosis and management of pericardial diseases. European Heart Journal 2004;25(7):587-610.

3. Liu PP, Mason JW. Advances in understanding of myocarditis. Circulation 2001;104(9):1076-82.

4. Dalldorf G, Sickles GM. An unidentified, filterable agent isolated from the feces of children with paralysis. Science 1948;108(2794):61-2. doi:10.1126/science.108.2794.61.

5. Hyypiä T, Kallajoki M, Maaronen M, et al. Pathogenetic differences between Coxsackie A and B virus infections in newborn mice. Virus Res 1993;27(1):71-8.

6. Montgomery J, Gear J, Prinsloo FR, et al. Myocarditis of newborn: outbreak in maternity home in southern Rhodesia associated with Coxsackie group B virus infection. South African Medical Journal 1955;29(26):608-12.

7. Creveld VS, De Jager H. Myocarditis in new born caused by Coxsackie virus: clinical and pathological data. Ann Paediatr 1956;187(1-2):100-18.

8. Fletcher E, Brennan CF. Cardiac complication of Coxsackie virus infection. Lancet 1957;272(6975):913-5.

9. Gordon RB, Lennete EH, Sandrock RS. The varied clinical manifestation of Coxsackie virus infections. Archives Of Internal Medicine 1959;103(1):63-75.

10. Null FC, Castle $\mathrm{CH}$. Adult pericarditis and myocarditis due to Coxsackie virus B type 5. New England Journal of Medicine 1959;261(19):937-42.

11. Sainani GS, Krompotic E, Slodki SJ. Adult heart disease due to Coxsackie $\mathrm{B}$ virus. Medicine (Baltimore) 1968;47(2):133-47.

12. Bell EJ, Grist NR. Further studies of enterovirus infections in cardiac disease and pleurodynia. Scand J Infect Dis 1970;2(1):1-6.

13. Sutton GC, Harding HB, Truehart RP, et al. Coxsackie B4 myocarditis in an adult: successful isolation of virus for ventricular myocardium. Clin Aviation Aerospace Med 1967;38:66-69.

14. Longson M, Cole FM, Davies D. Isolation of a Coxsackie virus group $\mathrm{b}$, type 5 , from the heart of a fatal case of myocarditis in an adult. Journal of Clinical Pathology 1969;22(6):654-8.

15. Bell EJ, Grist NR. Coxsackie virus infections in patients with acute cardiac disease and chest pain. Scottish Medical Journal 1968;13:47-51.

16. Freij L, Norrby R, Olsson B. A small outbreak of Coxsackie B5 infection with two cases of cardiac involvement and orchitis followed by testicular atrophy. Acta Medica Scandinavica 1970;187(1-6):177-81.
17. Smith WG. Coxsackie B myopericarditis in adults. American Heart Journal 1970;80(1):34-46.

18. Koontz CH, Ray CG. The role of Coxsackie group B virus infections in sporadic myopericarditis. American Heart Journal 1971;82(6):750-58.

19. Toshima H, Ohkita Y, Shingu M. Clinical features of acute Coxsackie B viral myocarditis. Japanese Circulation Journal 1979;43:441-4.

20. Sainani GS, Dekate MP, Rao CP. Heart disease caused by Coxsackie virus B infection. British Heart Journal I975;37(8):819-23.

21. Ferreira AG, Gomes MLC, Linhares AC, et al. Enteroviruses as a possible cause of myocarditis, pericarditis and dilated cardiomyopathy in Belém, Brazil. Brazilian Journal of Medical and Biological Research 1995;28(8):869-74.

22. Helin M, Savola J, Lapinleimu K, et al. Cardiac manifestations during a Coxsackie B5 epidemic. Brit Med J 1968;3(5610):97-9.

23. Dechkum N, Pangsawan Y, Jayavasu C, et al. Coxsackie B virus infection and myopericarditis in Thailand. 19871989 Southeast Asian J Trop Med Public Health 1998;29(2):273-6.

24. Schmidt NJ, Magoffin RL, Lennette EH. Association of group B Coxsackie viruses with cases of pericarditis, myocarditis, or pleurodynia by demonstration of immunoglobulin $\mathrm{m}$ antibody. American Society for Microbiology 1973;8(3):341-8.

25. Novikov IUI, Stulova MA, Lavrova IK. Myocarditis caused by Coxsackie $B$ viruses in adults. Ter Arkh 1984;56(11):37-43.

26. El-Hagrassy MM, Banatvala JE, Coltart DJ. Coxsackie B virus-specific IgM responses in patients with cardiac and other disease. Lancet 1980;2(8205):1160-2.

27. Frisk G, Torfason EG, Diderholm H. Reverse radioimmunoassays of $\operatorname{IgM}$ and IgG antibodies to Coxsackie B viruses in patients with acute myopericarditis. J Med Virol 1984;14(3):191-200.

28. O'Neill D, McArthur JD, Kennedy JA, et al. Coxsackie B virus infection in coronary care unit patients. J Clin Pathol 1983;36(6):658-61.

29. Joy J, Rao YY, Raveendranath M, et al. Coxsackie viral myocarditis: a clinical and echocardiographic study. Indian Heart J 1990;42(6):441-4.

30. Hashimoto $R$, Ogata $M$, Koga $Y$, et al. Clinical manifestations of acute Coxsackie $\mathrm{B}$ viral myocarditis and pericarditis with a special reference to serum enzyme patterns and long-term prognosis. The Kurume Medical Journal 1987;34(1):19-27. 